Jurnal IImiah Potensia, 2019, Vol. 4 (2), 115-120

https://ejournal.unib.ac.id/index.php/potensia

e-issn: 2621-2382 p-issn: 2527-9270

\title{
Peran Guru Dalam Mengembangkan Kemampuan Minat Baca Anak Usia Dini Melalui Metode Read Aloud
}

\author{
Agus Sumitra ${ }^{1}$ \\ delaguspiero@gmail.com \\ Nita Sumini ${ }^{2}$ \\ nitasumini@yahoo.com
}

1,2 Program Studi Pendidikan Guru Pendidikan Anak Usia Dini, IKIP Siliwangi Bandung

Received: January $23^{\text {rd }} 2019$

Accepted: July $26^{\text {th }} 2019$

Published: July $27^{\text {th }} 2019$

\begin{abstract}
Belum muncul dan belum berkembangnya minat baca anak dan cenderung lebih tertarik terhadap mainan didalam kelas, serta belum ada pembiasaan pengembangan minat baca oleh guru yang bersangkutan menjadi salah satu pe rmasalahan. Penelitian ini bertujuan: 1) Untuk mendeskripsikan perencanaan guru dalam mengembangkan minat baca anak usia dini melalui metode read aloud, 2) Untuk mendeskripsikan proses pelaksanaan guru dalam mengembangkan minat baca anak usia dini melalui metode read aloud, 3) Untuk mendeskripsikan evaluasi guru dan hasil yang dicapai dalam mengembangkan minat baca anak usia dini melalui metode read aloud. Metode yang digunakan untuk penelitian adalah kualitatif dengan metoda deskriptif. Hasil penelitian diperoleh data mengenai : 1) langkah langkah perencanaan guru dalam mengembangkan minat baca anak melalui metode read aloud, yaitu: pemilihan tujuan pembelajaran, tema dan subtema yang sesuai dengan rencana program semester, penentuan kegiatan belajar yang sesuai dengan aspek perkembangan anak seperti: nilai agama dan moral, sosial emosional, bahasa, kognitif, fisik motorik dan seni, 2) Proses pelaksanaan guru dalam mengembangkan kemampuan minat baca anak usia dini melalui metode read aloud di kelompok B Kober Misykatul Anwar, yaitu: pelaksanaan pembelajaran yang dengan RPPH, penataan lingkungan main yang sudah sesuai dengan tema dan tujuan pembelajaran minat baca menggunakan metode read aloud, 3) evaluasi dan penilaian pengembangan minat baca anak adalah sebagai berikut: guru sudah melakukan penilaian berdasarkan minat belajar, minat membaca, konsentrasi dan kemampuan menyimak, guru mendokumentasikan proses penilaian dengan cara mengumpulkan, menganalisa, menafsirkan dan mendisplay kejadian-kejadian selama proses kegiatan berlangsung, teknik penilaian menggunakan observasi dan running record.
\end{abstract}

Keywords: Peran Guru; Minat Baca; Metode Read Aloud

How to cite this article:

Sumitra, A., \& Sumini, N. (2019). Peran Guru Dalam Mengembangkan Kemampuan Minat Baca Anak Usia Dini Melalui Metode Read Aloud. Jurnal IImiah POTENSIA, 4(2), 115110. doi:https://doi.org/10.33369/iip.4.2.115-120

\section{PENDAHULUAN}

Menumbuhkan minat baca khususnya pada anak usia dini yang memiliki konsentrasi masih belum stabil dan daya fokusnya tidak bertahan lama menjadi tantangan tersendiri bagi civitas akademika di lingkungan PAUD. Akan tetapi sebagai guru PAUD merupakan suatu tantangan 
yang harus dihadapi sebagai bentuk profesionalisme sebagai seorang pendidik yang harus berdedikasi tinggi terhadap kemajuan pendidikan anak usia dini. Maka di Kober Misykatul Anwar, guru mencoba menerapkan metode read aloud untuk meningkatkan kemampuan minat baca pada anak usia dini.

Dalam metode read aloud ini, Buku menjadi salah satu media pembelajaran yang digunakan dalam meningkatkan kemampuan minat baca anak. Buku menjadi sumber pencerdasan bagi kehidupan manusia, banyak orang yang menjadi pintar karena kebiasaannya membaca (reading habit). Dalam hal ini pembiasan membaca harus ditanamkan sejak dini. Dengan membaca kemampuan berfikir manusia akan semakin terasah dan berkembang.

Orville Prescott (Jim Trelease: 2017) mengatakan dalam buku The Read Aloud Handbook "Tidak banyak anak - anak yang belajar mencintai buku dari dirinya sendiri. Harus ada orang yang memancing mereka masuk ke dalam dunia bahasa tertulis yang indah: seseorang harus menunjukkan jalan pada mereka." Dalam hal ini penulis memilih metode read aloud dalam meningkatkan minat baca pada anak usia dini. Menurut Hendry Guntur Tarigan (2015) read aloud adalah membaca dengan nyaring, membaca bersuara dan membaca lisan. Melalui metode ini, diharapkan dapat meningkatkan kemampuan minat baca sejak usia dini.

Beranjak dari permasalahan yang telah dipaparkan di atas, penulis merasa tertarik untuk mengetahui lebih lanjut tentang bagaimana hasil dari upaya guru dalam meningkatkan minat baca melalui metode read aloud.

Penelitian ini dilakukan dengan tujuan untuk meningkatkan kemampuan minat baca melalui metode read aloud di kelompok B Kober Misykatul Anwar.
Manfaat penelitian ini adalah a) secara teoritis, memberikan wawasan pengetahuan tentang masalah yang diteliti sehingga dapat diperoleh gambaran yang lebih jelas mengenai kesesuaian fakta dilapangan, b) secara praktis bagi lembaga, diharapkan mampu membantu lembaga dalam rangka memperbaiki proses belajar mengajar dan memotivasi guru untuk menerapkan metode yang bervariasi dalam pengajaran.

\section{Pendidikan Anak Usia Dini}

Pendidikan Anak Usia Dini (PAUD) adalah jenjang pendidikan sebelum jenjang pendidikan dasar yang merupakan suatu upaya pembinaan yang ditujukan bagi anak sejak lahir sampai dengan usia enam tahun yang dilakukan melalui pemberian rangsangan pendidikan untuk membantu pertumbuhan dan perkembangan jasmani dan rohani agar anak memiliki kesiapan dalam memasuki pendidikan lebih lanjut, yang diselenggarakan pada jalur formal, non formal dan informal.

\section{Minat Baca pada Anak Usia Dini}

Menurut Farida Rahim (2011:28) minat baca ialah keinginan yang kuat disertai usaha - usaha seeseorang untuk membaca. Orang yang mempunyai minat membaca yang kuat akan diwujudkannya dalam kesediaan untuk mendapat bahan bacaan dan kemudian membacanya atas kesadaran sendiri.

Menumbuhkan minat membaca pada anak jauh lebih penting daripada anak dapat cepat membaca. Adanya minat baca dari dalam diri seorang anak dapat ditandai ketika anak tersebut mengungkapkan kegemarannya dan cenderung lebih tertarik serta menyukai kegiatan membaca. anak akan mencurahkan perhatian yang lebih besar terhadap kegemarannya tersebut. Dengan kata lain minat adalah kesukaan dan ketertarikan seseorang terhadap suatu hal.

Untuk membangun kecintaan anak sejak dini bisa dimulai saat anak masih bayi, 
dengan membacakan berbagai buku cerita. Meyti H. Idris dan Izul Ramdahani (2015:21) mengemukakan bahwa walaupun anak belum mengerti apa yang dibacakan akan tetapi banyak manfaat yang dapat diperoleh, diantaranya a.) Menstimulasi perkembangan bahasa anak, b) Melatih memusatkan perhatian khususnya mendengar dan mengingat, c) Menstimulasi perkembangan informasi pada anak, d) Sebagai perkembangan sosial anak, e) Menstimulasi perkembangan kognitif pada anak, f) Membiasakan bayi pada buku sehingga kelak mencintai aktivitas membaca.

\section{Metode Read Aloud}

Pada membaca dalam hati, kita hanya mempergunakan ingatan visual (visual memory). Dalam hal ini, yang aktif adalah mata (pandangan;penglihatan) dan ingatan.sedangkan pada read aloud (membaca nyaring), selain penglihatan dan ingatan, juga turut aktif auditory memory (ingatan pendengaran) dan motor memory (ingatan yang bersangkut paut dengan otototot kita. (Moulton 1970:15).

Memang harus diakui bahwa hanya sedikit tujuan yang tercapai pada read loud (membaca nyaring) apabila buku yang dibacakan tidaklah menarik dan menyenangkan bagi anak. Read aloud adalah sebuah pendekatan yang dapat memuaskan serta memenuhi berbagai ragam tujuan serta mengembangkan sejumlah keterampilan serta minat anak salah satunya adalah minat baca. Oleh karena itu dalam mengajarkan keterampilan - keterampilan read aloud (membaca nyaring) guru harus memahami proses komunikasi dua arah.

Seorang pembaca nyaring yang baik biasanya berhasrat sekali menyampaikan sesuatu yang penting kepada para pendengarnya. Sesuatu yang penting itu dapat berupa informasi yang baru, pengalaman berharga, dan karakter yang menarik hati. Tanpa ada dorongan yang kuat untuk pembaca nyaring maka bacaan yang dibacakannya akan terasa hambar dan tidak hidup. Pembaca nyaring hendaklah mengetahui serta mendalami keinginan dan kebutuhan para pendengarnya, serta menginterpretasikan bahan bacaan itu secara tepat. Dalam hal ini pendengarnya adalah anak usia dini, sehingga pembaca harus bisa memilih bahan bacaan yang tepat dan menarik minat anak.

\section{METODE PENELITIAN}

Subyek penelitian dalam penelitian ini adalah siswa-siswa Kober Misykatul Anwar adalah kelompok B, dan dalam penelitian ini subyek yang diteliti berjumlah 9 siswa.

Penelitian yan dilaksanakan adalah penelitian Deskripstif Kualitatif, Teknik pengumpulan data yang digunakan adalah teknik observasi, wawancara, dan dokumentasi. Dokumentasi yang dilakukan berupa dokumentasi foto-foto maupun dokumentasi dokumen-dokumen yang digunakan guru maupun peneliti selama melakukan penelitian di lapangan.

Instrumen penelitian yang digunakan yaitu; a) lembar observasi, b) pedoman wawancara. Sedangkan langkah-langkah dalam melakukan penelitiannya adalah sebagai berikut; a) menyusun kisi - kisi penelitian, merupakan kerangka yang memudahkan dalam pengumpulan data, b) menyusun indikator penelitian, menyusun bagian - bagian mana saja yang akan dijadikan sebagai acuan observasi dilapangan sesuai rumusan masalah dan tujuan penelitian, c) menyusun pedoman wawancara, menyusun beberapa pertanyaan untuk menggali permasalahan yang ada dalam menggunakan metode read aloud, d) menyusun pedoman observasi, menyusun format - format observasi yang valid dan mendukung tercapainya tujuan penelitian.

\section{HASIL DAN PEMBAHASAN}

Penelitian deskriptif kualitatif dalam Peran Guru Dalam Mengembangkan 
Jurnal IImiah Potensia, 2019, Vol. 4 (2), 115-120

https://ejournal.unib.ac.id/index.php/potensia

e-issn: 2621-2382 p-issn: 2527-9270

Kemampuan Minat Baca Anak Usia Dini Melalui Metode Read Aloud (Penelitian dilaksanakan di Kelompok B Kober Misykatul Anwar) dilaksanakan dalam tiga tahap yaitu tahap perencanaan, pelaksanaan, dan evaluasi. Setelah dilaksanakannya metode Read Aloud dapat diketahui peningkatan kemampuan minat baca anak sangat meningkat berdasar analisis yang dilaksanakan oleh peneliti dan guru sebagai kolaborator, dapat diketahui bahwa penggunaan metode Read Aloud ini dapat meningkatkan kemampuan minat baca anak yang meliputi anak dapat menyukai buku, menambah kosakata baru, meningkatkan kemampuan menungkapkan ide, meningkatkan rasa ingin tahu, dan mengembangkan daya imajinasi anak.

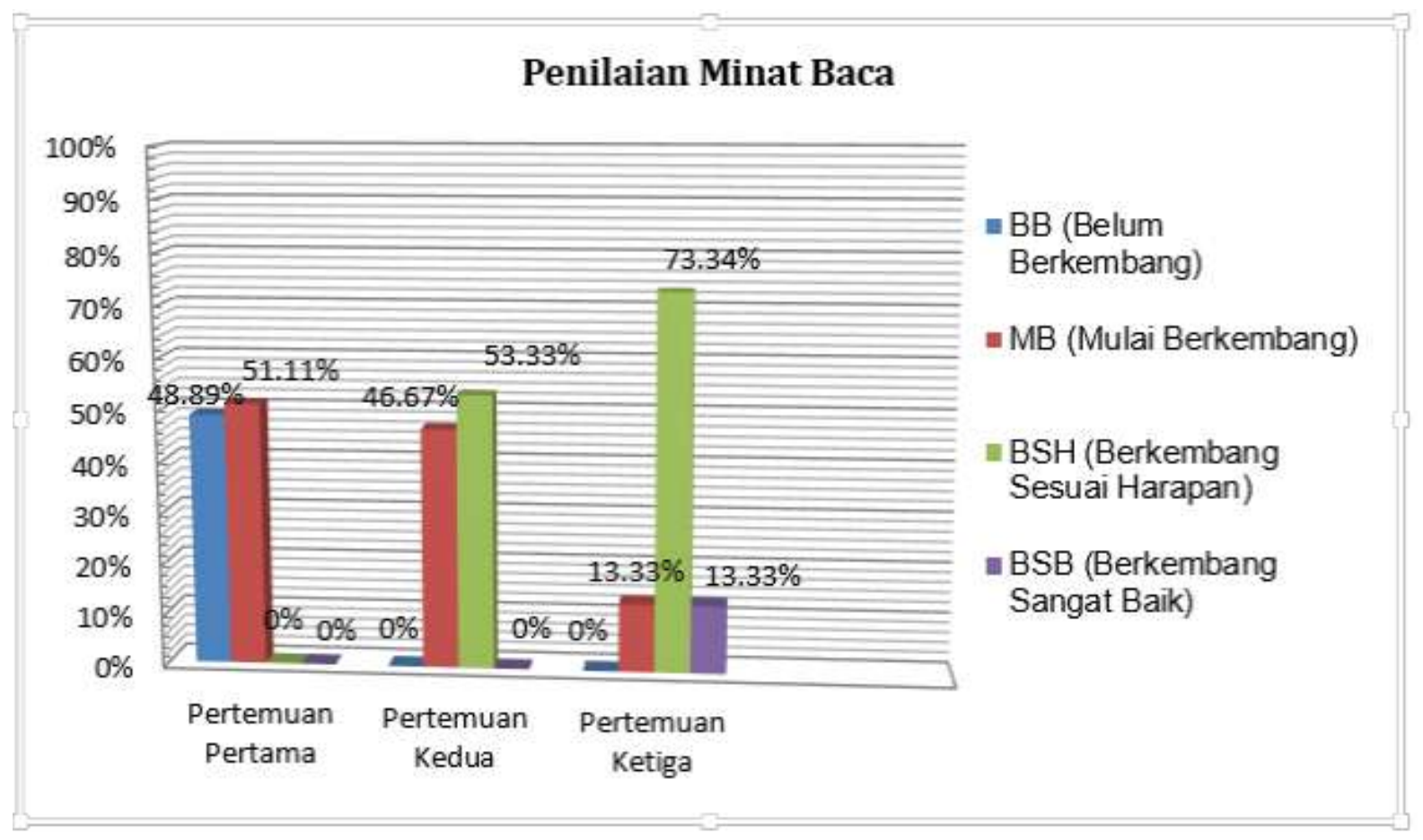

Gambar 1. Persentase Komulatif Penilaian Minat Baca 
Berdasarkan grafik pada gambar 1 dapat dijelaskan bahwa pertemuan pertama aspek penilaian minat baca pada kondisi awal BB (Belum Berkembang) menunjukkan setengahnya (48.89\%), MB (Belum Berkembang) lebih dari setengahnya (51.11\%), BSH (Berkembang Sesuai Harapan) tidak ada (0\%) dan BSB (Berkembang Sangat Baik) tidak ada (0\%). Sedangkan pada pertemuan kedua aspek penilaian minat baca BB (Belum Berkembang) menunjukkan tidak ada (0\%), $\mathrm{MB}$ (Belum Berkembang) hampir setengahnya (46.67\%), BSH (Berkembang Sesuai Harapan) lebih dari setengahnya (53.33\%) dan BSB (Berkembang Sangat Baik) tidak ada (0\%). Dan Aspek penilaian minat baca pada pertemuan ketiga BB (Belum Berkembang) menunjukkan tidak ada (0\%) , MB (Belum Berkembang) sebagian kecil (13.33\%), BSH (Berkembang Sesuai Harapan) lebih dari setengahnya (73.34\%) dan BSB (Berkembang Sangat Baik) sebagian kecil (13.33\%).

\section{KESIMPULAN}

Evaluasi dan hasil yang dicapai dalam mengembangkan kemampuan minat baca anak usia dini melalui metode read aloud di kelompok B Kober Misykatul Anwar adalah sebagai berikut: guru sudah melakukan penilaian berdasarkan minat belajar, minat membaca, konsentrasi dan kemampuan menyimak, guru mendokumentasikan proses penilaian dengan cara mengumpulkan, menganalisa, menafsirkan dan mendisplay kejadian - kejadian selama proses kegiatan berlangsung, teknik penilaian menggunakan observasi dan running record. Observasi merupakan pengamatan dan pencatatan secara sistematis terhadap gejala yang nampak pada objek yang diamati. Sedangkan running records merupakan teknik penilaian dengan cara menuliskan atau mencatat secara rinci segala hal yang dilakukan dan diucapkan oleh anak, ditulis langsung pada saat mengamati anak

\section{Saran}

Dalam hal perencanaan, guru diharapkan mampu menguasai dan menggali berbagai informasi mengenai kurikulum PAUD 2013, pengetikan RPPH dilakukan secara komputerisasi serta menjadwalkan kegiatan pengembangan minat baca anak menggunakan metode read aloud.

Dalam hal pelaksanaan pembelajaran, guru sebaiknya menyiapkan alat dan bahan pembelajaran yang sesuai dengan RPPH yang telah dibuat, guru harus dapat mengendalikan suasana kelas sehingga pengelolaan kelas menjadi kondusif, guru dapat memberikan perhatian dan penghargaan bagi peserta didik

Dalam hal evaluasi penilaian pembelajaran dilaksanakan berkesinanbungan, terencana dan terus menerus sehingga pengembangan minat baca melalui metode read aloud menjadi seuatu kebiasaan membaca bagi anak usia dini.

\section{DAFTAR PUSTAKA}

Abidin, Y. (2016). Pembelajaran Membaca Berbasis Pendidikan Karakter. Bandung. Refika Aditama

Arikunto, S. (2002). Prosedur Penelitian Suatu Pendekatan dan Praktek. Jakarta: Rineka Cipta

Dheini, N.. (2005). Metode Pengembangan Bahasa. Jakarta: Universitas Terbuka

Departemen Pendidikan dan kebudayaan (2002). Kamus Besar Bahasa Indonesia. Jakarta: Balai Pustaka

Departemen Pendidikan Nasional (2007). Menebar Teladan Melalui Karya 
Nyata. Jakarta: Departemen

Pendidikan Nasional

Depdikbud (2001). Petunjuk Pelaksanaan Pembinaan dan Pengembangan Olahraga. Jakarta: Balai Pustaka

Depdiknas (2001). Pedoman Penyelenggaraan Pendidikan pada Taman Penitipan Anak. Jakarta: Depdiknas

Fadilah, M. \& Lilif, M. (2013) Pendidikan Karakter Anak Usia Dini Konsep dan Aplikasinya dalam PAUD. Yogyakarta: Ar-russ Media.

Ginting, V. (2005). Penguatan Membaca, Fasilitas Lingkungan Sekolah dan Keterampilan Dasar membaca bahasa Indonesia Serta Minat Baca Murid. Jurnal Pendidikan Penabur. No 04/th.IV

Hurlock, E. B. (1978). Perkembangan Anak (Jilid 2 Edisi ke Enam). Jakarta: Erlangga

Ibrahim, R dan Nana Syaodih, S. (2003). Perencanaan Pengajaran. Jakarta: Rineka Cipta

Idris, M. H \& Ramdani, I. (2015). Menumbuhkan Minat Membaca pada Anak Usia Dini. Jakarta: Luxima Metro Media

Kartono, K. (1996). Pengantar Metodologi Riset Sosial. Bandung: Mandar Maju

Margono (2000). Metodologi Penelitian Pendidikan. Jakarta: Rineka Cipta

Mursid. (2016). Belajar dan Pembelajaran PAUD. Bandung: Rosdakarya.

Moleong. (2001). Metode Penelitian Kualitatif. Bandung: Rosdakarya
Moulton, W. G. (1970). A Linguistic Guide to Language Learning. New York: Modern Language Association of America

Nasution, S. (2009). Metode Research. Bandung: Bumi Aksara

Ngalimun. (2014). Strategi dan Model Pembelajaran. Yogyakarta: Aswaja Pressindo

Rahim, F. (2008). Pengajaran Membaca di Sekolah Dasar. Jakarta: Bumi Aksara.

Semiawan, C. $\mathrm{R}$ (2005). Penerapan Pembelajaran pada Anak. Jakarta: Indeks.

Saryono. (2010). Metodologi Penelitian Kualitatif Dalam Bidang Kesehatan. Yogyakarta: Nuha Medika

Solehudin, M. (2000). Konsep Dasar Pendidikan Prasekolah. Fakultas Ilmu Pendidikan UPI Bandung.

Sugiyono. (2017). Metode Penelitian Kombinasi. Bandung: Alfabeta

Sudjana, N. (1990). Penilaian Hasil Belajar Mengajar. Bandung: Sinar Baru

Sukmadinata, N. S. (2012). Metode Penelitian Pendidikan. Bandung: Remaja Rosda Karya

Tafsir, A. (2005). Ilmu Pendidikan Dalam Perspektif Islam. Bandung: Remaja Rosda Karya

Tarigan, H.G. (2015). Membaca Sebagai Suatu Keterampilan Berbahasa. Bandung: Angkasa.

Trelease, J. (2017). The Read-Aloud Handbook. New York: Penguin (USA) LLC. 